\title{
Thermosipho atlanticus sp. nov., a novel member of the Thermotogales isolated from a Mid-Atlantic Ridge hydrothermal vent
}

\author{
Correspondence \\ Georges Barbier \\ Georges.Barbier@ifremer.fr \\ or \\ Georges.Barbier@univ-brest.fr
}

\author{
Laurent Urios, ${ }^{1}$ Valérie Cueff-Gauchard, ${ }^{1}$ Patricia Pignet, ${ }^{1}$ Anne Postec, ${ }^{1}$ \\ Marie-Laure Fardeau, ${ }^{2}$ Bernard Ollivier ${ }^{2}$ and Georges Barbier ${ }^{1}$ \\ ${ }^{1}$ Laboratoire de Microbiologie et de Biotechnologie des Extrêmophiles, IFREMER, \\ Centre de Brest, BP 70, 29280 Plouzané, France \\ ${ }^{2}$ Laboratoire IRD de Microbiologie des Anaérobies, UR 101, Universités de Provence et de la \\ Méditerranée, CESB-ESIL, case 925, 163 Avenue de Luminy, 13288 Marseille, France
}

\begin{abstract}
A novel anaerobic, thermophilic and heterotrophic bacterium, designated strain $\mathrm{DV} 1140^{\top}$, was isolated from a deep-sea hydrothermal vent sample from the Mid-Atlantic Ridge. The cells were non-motile straight rods, $1.8 \mu \mathrm{m}$ long and $0.4 \mu \mathrm{m}$ wide, surrounded by an outer sheath-like structure (toga). They grew at $45-80^{\circ} \mathrm{C}$ (optimum $65^{\circ} \mathrm{C}$ ), $\mathrm{pH} 5 \cdot 0-9 \cdot 0$ (optimum $\mathrm{pH} \mathrm{6.0)}$ ) and at sea salt concentrations of $20-60 \mathrm{~g} \mathrm{I}^{-1}$ (optimum $30 \mathrm{~g} \mathrm{I}^{-1}$ ). Strain DV $1140^{\top}$ was able to ferment yeast extract, peptone, brain heart infusion, gelatin, starch, galactose, arabinose, glucose, trehalose and cellobiose. The fermentation products identified on glucose in the presence of yeast extract and peptone were acetate, isovalerate and hydrogen. The $\mathrm{G}+\mathrm{C}$ content of the genomic DNA was 33 mol\%. Phylogenetic analysis of the 16S rRNA gene sequence (GenBank accession number AJ577471) located the strain within the genus Thermosipho in the bacterial domain. On the basis of 16S rRNA gene sequence comparisons, and physiological and biochemical characteristics, the isolate represents a novel species, for which the name Thermosipho atlanticus sp. nov. is proposed. The type strain is DV $1140^{\top}(=\mathrm{CIP}$ $108053^{\top}=$ DSM $15807^{\top}$ ).
\end{abstract}

Members of the order Thermotogales have been isolated from various extreme environments such as hot springs, oil reservoirs and marine hydrothermal vents. They are anaerobic, thermophilic and heterotrophic bacteria characterized by the presence of a toga, an outer sheath-like structure surrounding the cells. The order Thermotogales includes six genera: Fervidobacterium, Thermotoga, Geotoga, Petrotoga, Marinitoga and Thermosipho. At the time of writing, only four species belonging to the genus Thermosipho have been described: Thermosipho africanus (Huber et al., 1989), Thermosipho japonicus (Takai \& Horikoshi, 2000), Thermosipho melanesiensis (Antoine et al., 1997) and Thermosipho geolei (L'Haridon et al., 2001). Thermosipho africanus $\mathrm{Ob}^{\mathrm{T}}$ was isolated from a coastal hydrothermal spring. Thermosipho japonicus $\mathrm{IHB}^{\mathrm{T}}$ and Thermosipho melanesiensis $\mathrm{BI} 429^{\mathrm{T}}$ were isolated from deep marine hydrothermal vents. Thermosipho geolei SL $31^{\mathrm{T}}$ was isolated from a deep continental oil reservoir. In this study we report the description of a novel thermophilic

Published online ahead of print on 7 May 2004 as DOI 10.1099/ ijs.0.63069-0.

The GenBank/EMBL/DDBJ accession number for the 16S rRNA gene sequence of strain DV $1140^{\top}$ is AJ577471. bacterium isolated from a deep-sea hydrothermal vent chimney, and assign this to a novel species within the genus Thermosipho.

Different types of samples were collected by the humanoperated submersible Nautile in 1994 during the DIVA2 cruise on deep-sea vent fields of the Mid-Atlantic Ridge: Lucky Strike $\left(32^{\circ} 16^{\prime} \mathrm{W} 37^{\circ} 17^{\prime} \mathrm{N}\right.$; 1600-1700 m water depth) and Menez-Gwen ( $31^{\circ} 31^{\prime} \mathrm{W} 37^{\circ} 51^{\prime} \mathrm{N}$; 800-1000 m water depth). Fragments of an active black smoker chimney were collected by the DSV Nautile at Menez-Gwen and placed in an insulated box previously filled with sterile sea water. The box was opened in an on-board laboratory under sterile conditions. Friable pieces of chimney wall were crushed in an anaerobic chamber after addition of sterile sea water. Subsamples were transferred in cryotubes with $5 \%$ DMSO and in serum vials stored, respectively, at $-70{ }^{\circ} \mathrm{C}$ and $4{ }^{\circ} \mathrm{C}$.

For inoculations, contents from one serum vial $(10 \mathrm{ml})$ and one cryotube $(1.8 \mathrm{ml})$ were mixed and diluted to $60 \mathrm{ml}$ with $23 \mathrm{~g} \mathrm{l}^{-1} \mathrm{NaCl}$. Enrichments $(1 \mathrm{ml}$ inoculum in $20 \mathrm{ml}$ culture medium) and isolations were performed using PEXS medium (Urios et al., 2004) at different temperatures (50, 65 and $\left.80^{\circ} \mathrm{C}\right)$. Positive cultures were determined by 
microscopic observations and then purified. One isolate obtained at $65^{\circ} \mathrm{C}$ was referenced as strain $\mathrm{DV} 1140^{\mathrm{T}}$. Single colonies of this isolate were obtained by streaking on PEXS medium solidified with $15 \mathrm{~g} \mathrm{l}^{-1}$ Gelrite (Scott Laboratories). Plates were incubated in anaerobic jars for 3 days at $65^{\circ} \mathrm{C}$. Colonies were subsequently picked and streaked twice under the same conditions.

Microscope observations indicated that cells of isolate DV $1140^{\mathrm{T}}$ were non-motile straight rods surrounded by a sheath-like structure. Cells were approximately $1 \cdot 8 \pm 0 \cdot 8 \mu \mathrm{m}$ long and $0 \cdot 4 \pm 0 \cdot 2 \mu \mathrm{m}$ wide (mean $\pm 95 \%$ confidence interval) and appeared singly or in short chains. Cells were negatively stained for transmission electron microscopy (Raguénès et al., 1997). No flagella were observed. The presence of a toga was observed (Fig. 1). The Ryu $\mathrm{KOH}$ reaction (Powers, 1995), leading to immediate cell lysis as confirmed by phase-contrast microscopy, was positive, indicating that the cells were Gram-negative.

The isolate was usually grown on glucose/yeast extract/ peptone/sea salts (GYPS) medium containing $\left(1^{-1}\right): 5 \mathrm{~g}$ $(+)$ D-glucose (Sigma), $0.5 \mathrm{~g}$ yeast extract (Difco), $1 \mathrm{~g}$ bacto-peptone (Difco), $30 \mathrm{~g}$ sea salts (Sigma), 6.05 g PIPES buffer (Sigma) and $0 \cdot 1 \%(\mathrm{v} / \mathrm{v})$ resazurin solution. The $\mathrm{pH}$ was adjusted to 6.0 before autoclaving for $20 \mathrm{~min}$ at $121{ }^{\circ} \mathrm{C}$. The medium was reduced by adding $0.5 \mathrm{~g}$ sodium sulfide before inoculation. Cultures were incubated at $65^{\circ} \mathrm{C}$ under anaerobic conditions, $\mathrm{N}_{2} / \mathrm{H}_{2} / \mathrm{CO}_{2}(90: 5: 5)$, at atmospheric pressure. Methods for the determination of growth parameters and enumeration of cells were as reported by Wery et al. (2001b). Growth was observed at $45-80{ }^{\circ} \mathrm{C}$ with the optimum temperature $65^{\circ} \mathrm{C}$. The strain required marine salts for growth, and grew at sea salt concentrations of 20-60 $\mathrm{g} \mathrm{l}^{-1}$ (corresponding to 15-46 g $\mathrm{NaCl} \mathrm{l}^{-1}$ ). No significant growth was observed at concentrations of 10 or $80 \mathrm{~g} \mathrm{l}^{-1}$. The optimum sea salt concentration was approximately $30 \mathrm{~g} \mathrm{l}^{-1}$ (corresponding to $23 \mathrm{~g}$ $\left.\mathrm{NaCl} 1^{-1}\right)$. Growth occurred at $\mathrm{pH} 5 \cdot 0-9 \cdot 0$, and the optimum $\mathrm{pH}$ was $6 \cdot 0$. Growth rate decreased to $50 \%$ at $\mathrm{pH} 7.0$ and to $60 \%$ at $\mathrm{pH} 8.0$ in comparison with that at $\mathrm{pH} 6 \cdot 0$. Under optimal conditions, the maximum cell concentration obtained was $2 \times 10^{8}$ cells ml $\mathrm{ml}^{-1}$ and the shortest generation time observed was $72 \mathrm{~min}$.

The ability to use different carbon sources was investigated by adding one of the following compounds to a final concentration of $0.5 \%(\mathrm{w} / \mathrm{v})$ instead of glucose to the GYPS medium: sucrose, cellobiose, xylose, starch, lactate, maltose, mannose, trehalose, lactose, arabinose, galactose, mannitol, peptone, Casamino acids, casein, gelatin and brain heart infusion (BHI). Weak growth was observed in the presence of yeast extract and peptone (YPS). Growth yield of strain DV $1140^{\mathrm{T}}$ was enhanced either by replacing yeast extract or peptone with $2 \mathrm{~g} \mathrm{BHI} 1^{-1}$ or by the addition of gelatin, starch, galactose, arabinose, glucose, trehalose or cellobiose to YPS. Amino acids and organic acids were analysed as metabolic end products by means of HPLC as described by Wery et al. (2001b). Production of $\mathrm{H}_{2} \mathrm{~S}$ from elemental sulfur was investigated using lead acetate paper and $5 \mathrm{mM} \mathrm{CuSO}_{4} / 50 \mathrm{mM} \mathrm{HCl}$ as indicated by Alain et al. (2002). $\mathrm{H}_{2}$ and $\mathrm{H}_{2} \mathrm{~S}$ were also quantified as described by Cord-Ruwisch (1985) and Fardeau et al. (1993). $\mathrm{H}_{2} \mathrm{~S}$ production was observed and compared with that for controls (sterile GYPS medium with or without elemental sulfur) in the presence of $10 \mathrm{~g} \mathrm{l}^{-1}$ elemental sulfur in GYPS medium. During GYPS fermentation until stationary phase, $5.6 \mathrm{mM}$ glucose was consumed, and $1.7 \mathrm{mM}$ acetate, $0.14 \mathrm{mM}$ isovalerate and $12.5 \mathrm{mM} \mathrm{H}_{2}$ were produced. $\mathrm{H}_{2} \mathrm{~S}$ was not detected. Fermentation in the presence of $10 \mathrm{~g}$ elemental sulfur $1^{-1}$ in GYPS led to consumption of $6.0 \mathrm{mM}$ glucose and production of $1.9 \mathrm{mM}$ acetate, $0.15 \mathrm{mM}$ isovalerate, $7.5 \mathrm{mM} \mathrm{H}_{2}$ and $1.3 \mathrm{mM} \mathrm{H}_{2} \mathrm{~S}$. Acetate and isovalerate were the only organic acids detected in both experiments. Amino acid analysis revealed an increase of $10 \mathrm{mg}$ glycine $\mathrm{l}^{-1}, 3 \mathrm{mg}$ alanine $\mathrm{l}^{-1}$ and $10 \mathrm{mg}$ proline $\mathrm{l}^{-1}$ in the culture medium as compared with controls.

The requirement for an external electron acceptor was tested. Only a slight enhancement of growth yield (16\%) was observed in the presence of $50 \mathrm{mM}$ cystine. No significant differences with regard to growth kinetics and maximum cell concentrations $\left(2 \times 10^{8} \mathrm{cells} \mathrm{ml}^{-1}\right)$ were noticed during cultures on GYPS medium with or without elemental sulfur $\left(10 \mathrm{~g} \mathrm{l}^{-1}\right)$. Polysulfides (Blumentals et al., $1990)$, sodium thiosulfate (20 mM), sodium sulfite (20 mM), sodium sulfate $(20 \mathrm{mM})$, sodium nitrite $(20 \mathrm{mM})$ and sodium nitrate $(20 \mathrm{mM})$ did not enhance growth. No difference in growth was noticed between GYPS medium conditioned in an anaerobic chamber with or without

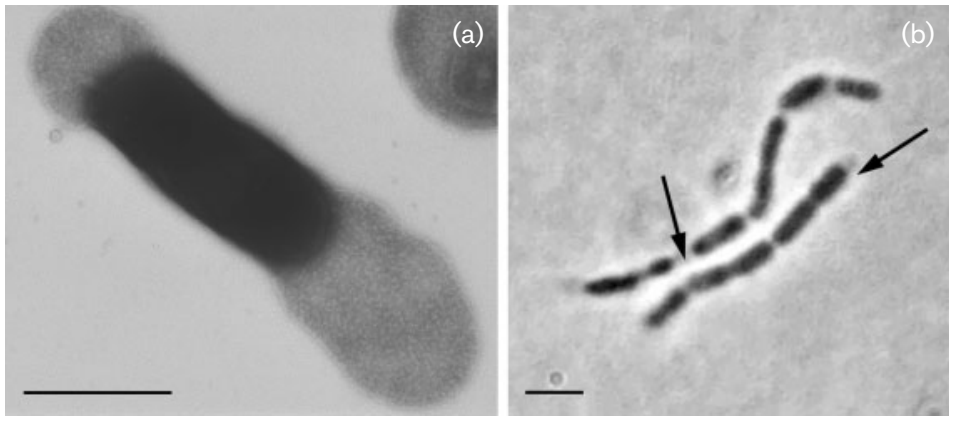

Fig. 1. (a) Electron micrograph of a negatively stained cell of strain DV $1140^{\top}$ showing the toga at each end. Bar, $1 \mu \mathrm{m}$. (b) Phasecontrast micrograph of cells in chains. The sheath-like structure surrounding the cells is indicated by arrows. Bar, $1 \mu \mathrm{m}$. 
$\mathrm{Na}_{2} \mathrm{~S}$. In this last case, a $\mathrm{N}_{2}$ flow was applied for $10 \mathrm{~min}$ after vacuum extraction.

The effect of $\mathrm{H}_{2}$ concentrations in the gas phase $\left(\mathrm{N}_{2} / \mathrm{H}_{2}\right.$ at $100: 0,90: 10,75: 25,50: 50,25: 75$ and $10: 90)$ was studied for DV1140 ${ }^{\mathrm{T}}$ and Thermosipho geolei SL31 ${ }^{\mathrm{T}}$ when grown in GYPS and in the medium described by L'Haridon et al. (2001), respectively. For both strains, the highest mean maximal concentrations from triplicate experiments at the end of the exponential phase were observed with $0 \%$ $\mathrm{H}_{2}$ (respectively $3.6 \times 10^{8}$ and $9 \cdot 6 \times 10^{7}$ cells $\mathrm{ml}^{-1}$ ) and decreased linearly with an increase in $\mathrm{H}_{2}$. We estimated from linear regressions that growth was completely inhibited with $87 \% \mathrm{H}_{2}$ for Thermosipho geolei SL31 ${ }^{\mathrm{T}}$ and with $29 \%$ $\mathrm{H}_{2}$ for DV $1140^{\mathrm{T}}$. Congruently, no significant growth was observed for Thermosipho geolei SL31 ${ }^{\mathrm{T}}$ with $80 \% \mathrm{H}_{2}$ (L'Haridon et al., 2001).

Susceptibility to oxygen was investigated by incubating DV $1140^{\mathrm{T}}$ in GYPS medium, with or without elemental sulfur, under $\mathrm{O}_{2}$ concentrations up to $12 \%$ of the gas phase. The initial gas phase of the culture medium $\left(\mathrm{N}_{2} /\right.$ $\left.\mathrm{H}_{2} / \mathrm{CO}_{2} 90: 5: 5\right)$ was replaced after vacuum extraction by different calibrated mixtures of $\mathrm{N}_{2}$ and $\mathrm{N}_{2} / \mathrm{O}_{2}(80: 20)$. In GYPS medium, growth was noticed up to $4 \% \mathrm{O}_{2}$. A decrease of $43 \%$ of the maximum cell concentration occurred at $2 \% \mathrm{O}_{2}$ and of $63 \%$ at $4 \% \mathrm{O}_{2}$, in comparison with a control comprising the same medium with a gas phase containing only $\mathrm{N}_{2}$. No growth was observed for a concentration of $6 \%$. In GYPS medium with elemental sulfur $\left(10 \mathrm{~g} \mathrm{l}^{-1}\right)$, significant growth was obtained up to $8 \% \mathrm{O}_{2}$. The maximum cell concentration decreased by $15 \%$ at $4 \%$ $\mathrm{O}_{2}, 25 \%$ at $8 \% \mathrm{O}_{2}$ and $97 \%$ at $10 \% \mathrm{O}_{2}$ in comparison with the control comprising the same medium with a gas phase containing only $\mathrm{N}_{2}$. No significant difference appeared between controls with $\mathrm{N}_{2}$ or $\mathrm{N}_{2} / \mathrm{H}_{2} / \mathrm{CO}_{2}(90: 5: 5)$ gas phases. This resistance to $\mathrm{O}_{2}$ was comparable with the results obtained for Thermotoga strains (Van Ooteghem et al., 2001).

Genomic DNA was extracted as described by Wery et al. (2001a). The DNA was purified by $\mathrm{CsCl}$ gradient centrifugation (Wery et al., 2001b) and the $\mathrm{G}+\mathrm{C}$ content was determined by thermal denaturation according to the method of Marmur \& Doty (1962) under the conditions reported by Raguénès et al. (1997). The $\mathrm{G}+\mathrm{C}$ content of the genomic DNA of strain DV1140 ${ }^{\mathrm{T}}$ was $33 \mathrm{~mol} \%$. The $16 \mathrm{~S}$ rRNA gene was selectively amplified as described by Wery et al. (2001b) and the PCR product was sequenced using the primers described by Raguénès et al. (1996). This almost complete sequence of 1511 bp was then compared with others available in GenBank using BLAST (Altschul et al., 1997). A multiple sequence file was obtained by using the MEGALIGN program of the DNASTAR package (Promega). Alignments and similarity levels were obtained by the CLUSTAL $\mathrm{W}$ method with weighted residues (Thompson et al., 1994). Alignments were manually corrected using the multiple sequence alignment editor SEAVIEW and the phylogenetic reconstruction was produced using PHYLO_WIN (Galtier et al., 1996) with the following algorithms: Jukes-Cantor distance matrix and successively the neighbour-joining (Saitou \& Nei, 1987), maximumparsimony and maximum-likelihood methods (Felsenstein, 1981). Bootstrap values were determined according to Felsenstein (1985). Strain DV1140 ${ }^{\mathrm{T}}$ was phylogenetically affiliated to the genus Thermosipho (Fig. 2). The nearest recognized relatives were Thermosipho africanus $\mathrm{Ob}^{\mathrm{T}}$ $\left(=\mathrm{DSM} 5309^{\mathrm{T}}\right)$, Thermosipho melanesiensis BI429 ${ }^{\mathrm{T}}(=\mathrm{DSM}$ $\left.12029^{\mathrm{T}}\right)$, Thermosipho japonicus $\mathrm{IHB}^{\mathrm{T}}\left(=\mathrm{JCM} 10495^{\mathrm{T}}\right)$ and Thermosipho geolei SL31 ${ }^{\mathrm{T}}\left(=\mathrm{DSM} 13256^{\mathrm{T}}\right)$, with sequence similarity values of $91,92,94$ and $96 \%$, respectively. Pairwise evolutionary distances were computed by use of Kimura's two-parameter model (Kimura, 1980) and a dendrogram was constructed from these distances by use of the neighbour-joining method. The positioning of strain DV $1140^{\mathrm{T}}$ was supported by the results of the three algorithms used.

A screening of eventual different enzymic activities was performed using the API ZYM system (bioMérieux) for strain DV1140 ${ }^{\mathrm{T}}$ and Thermosipho geolei SL31 ${ }^{\mathrm{T}}$, its nearest relative. This system, comprising 20 reactions, has already been used to aid in identification of bacteria according to the enzymic profiles obtained (Gauthier, 1976; Hofstad, 1980; Kilian, 1978; Tharagonnet et al., 1977). The test was performed at $65^{\circ} \mathrm{C}$ in duplicate. Three differences were revealed between the two strains: leucine arylamidase, valine arylamidase and $\alpha$-chymotrypsin reactions were only positive for strain DV1140 ${ }^{\mathrm{T}}$.

Strain DV $1140^{\mathrm{T}}$ corresponds with the major characteristics of the Thermotogales. Strain DV1140 ${ }^{\mathrm{T}}$ and its nearest relative Thermosipho geolei SL31 ${ }^{\mathrm{T}}$ (L'Haridon et al., 2001) present a similar cell morphology, but they differ with

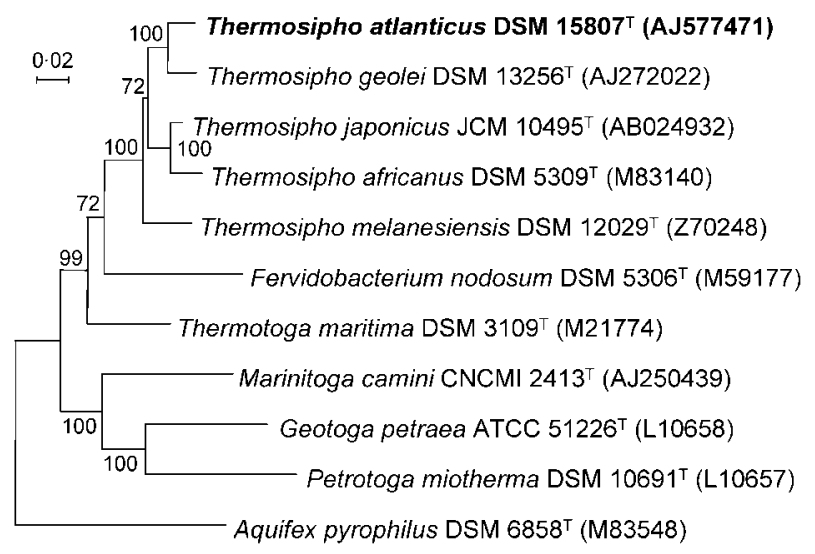

Fig. 2. Phylogenetic position of strain $D V 1140^{\top}$ within the order Thermotogales. Aquifex pyrophilus was used as the outgroup. Accession numbers and type strains are indicated. The topology shown corresponds to an unrooted tree obtained by a neighbour-joining algorithm (Kimura corrections) established using PHYLO_WIN and manually refined using SEAVIEW. Bootstrap values are displayed on their relative branches. 
Table 1. Discriminating characteristics of Thermosipho species

Strains: 1, T. africanus $\mathrm{Ob7}^{\mathrm{T}}$ (data from Huber et al., 1989); 2, T. melanesiensis BI429 ${ }^{\mathrm{T}}$ (Antoine et al., 1997); 3, T. geolei SL31 ${ }^{\mathrm{T}}$ (L'Haridon et al., 2001); 4, T. japonicus IHB1 ${ }^{\mathrm{T}}$ (Takai \& Horikoshi, 2000); 5, strain DV1140 ${ }^{\mathrm{T}}$ (this work). +, Positive; -, negative; $(+)$, weakly positive; $(+\mathrm{Y})$, in the presence of yeast extract; $(+\mathrm{C})$, in the presence of casein; ND, not determined. All strains produce $\mathrm{H}_{2} \mathrm{~S}$ with sulfur.

\begin{tabular}{|c|c|c|c|c|c|}
\hline Characteristic & 1 & 2 & 3 & 4 & 5 \\
\hline \multicolumn{6}{|l|}{ Origin: } \\
\hline Place & Tadjoura gulf & Lau Basin & Western Siberia & Iheya Basin & Mid-Atlantic Ridge \\
\hline Environment & $\begin{array}{l}\text { Hydrothermal } \\
\text { springs }\end{array}$ & $\begin{array}{l}\text { Hydrothermal } \\
\text { vent }\end{array}$ & $\begin{array}{l}\text { Continental } \\
\text { oil reservoir }\end{array}$ & $\begin{array}{l}\text { Hydrothermal } \\
\text { vent }\end{array}$ & Hydrothermal vent \\
\hline Sample & $\begin{array}{c}\text { Water and } \\
\text { sediment }\end{array}$ & $\begin{array}{c}\text { Gills of } \\
\text { Bathymodiolus }\end{array}$ & $\begin{array}{l}\text { Water/oil } \\
\text { mixture }\end{array}$ & Chimney & Chimney \\
\hline $\mathrm{G}+\mathrm{C}$ content $(\mathrm{mol} \%)$ & $29-30$ & $30 \cdot 5$ & 30 & $31 \cdot 4$ & 33 \\
\hline Flagella & ND & $\mathrm{ND}$ & 1 polar & No & No \\
\hline \multicolumn{6}{|l|}{ Growth conditions: } \\
\hline $\mathrm{pH}$ range & $6-8$ & $4 \cdot 5-8 \cdot 5$ & $6-9 \cdot 4$ & $5 \cdot 3-9 \cdot 3$ & $5 \cdot 0-9 \cdot 0$ \\
\hline pH optimum & $7 \cdot 2$ & $6 \cdot 5-7 \cdot 5$ & $7 \cdot 5$ & $7 \cdot 2-7 \cdot 6$ & $6 \cdot 0$ \\
\hline Doubling time $(\mathrm{min})$ & 35 & 100 & 115 & 45 & 72 \\
\hline Oxygen resistance & $\mathrm{ND}$ & - & - & - & up to $4 \%(\mathrm{v} / \mathrm{v})$ \\
\hline \multicolumn{6}{|l|}{ Substrates used: } \\
\hline Starch & + & $(+\mathrm{Y})+$ & - & $(+C)+$ & $(+\mathrm{Y})+$ \\
\hline Galactose & $(+)$ & $(+\mathrm{Y})+$ & - & $(+\mathrm{C})+$ & $(+\mathrm{Y})+$ \\
\hline Lactose & - & $(+\mathrm{Y})+$ & ND & ND & ND \\
\hline Arabinose & - & $\mathrm{ND}$ & - & ND & $(+\mathrm{Y})+$ \\
\hline Maltose & + & $(+\mathrm{Y})+$ & - & $(+\mathrm{Y})+$ & - \\
\hline Sucrose & $(+)$ & $(+\mathrm{Y})+$ & - & $(+\mathrm{C})+$ & - \\
\hline \multicolumn{6}{|l|}{ Stimulation of growth by: } \\
\hline Elemental sulfur & + & + & + & + & - \\
\hline Thiosulfate & + & - & - & + & - \\
\hline $\mathrm{H}_{2} \mathrm{~S}$ production with thiosulfate & + & - & - & + & - \\
\hline $\mathrm{H}_{2}$ concentration that inhibits growth (\%) & $\leqslant 80$ & $\leqslant 80$ & 87 & $\leqslant 80$ & 29 \\
\hline
\end{tabular}

regard to production of $\mathrm{H}_{2} \mathrm{~S}$ in the presence of elemental sulfur, growth on glucose, peptone and yeast extract, a (slight) stimulation of growth with cystine and $96 \% 16 \mathrm{~S}$ rRNA gene sequence similarity (Table 1). Their geographical origins are very dissimilar. No flagella were found with DV $1140^{\mathrm{T}}$ cells, regardless of the growth phase. The $\mathrm{pH}$ optimum is clearly different (DV1 $140^{\mathrm{T}}$ has the lowest $\mathrm{pH}$ observed for Thermosipho species). Under usual anaerobic culture conditions, the presence of elemental sulfur had no visible effect on growth kinetics and maximum cell concentrations, but a minor effect on glucose fermentation products. Consequently, strain $\mathrm{DV} 1140^{\mathrm{T}}$ is the only Thermosipho strain that remains unaffected by elemental sulfur for growth. Strain DV1140 ${ }^{\mathrm{T}}$ is able to grow at $\mathrm{O}_{2}$ concentrations up to $8 \%$ in the presence of elemental sulfur and up to $4 \% \mathrm{O}_{2}$ without elemental sulfur, whereas growth of Thermosipho geolei $\mathrm{SL} 31^{\mathrm{T}}$ is inhibited at lower concentrations $\left(0 \cdot 2-1 \cdot 0 \% \mathrm{O}_{2}\right)$. Growth of DV1140 ${ }^{\mathrm{T}}$ and Thermosipho geolei SL31 ${ }^{\mathrm{T}}$ are inhibited with 29 and $87 \%$ $\mathrm{H}_{2}$ in the gas phase, respectively. Strain DV $1140^{\mathrm{T}}$ was able to grow on galactose, arabinose, starch and gelatin, which are not used by Thermosipho geolei SL $31^{\mathrm{T}}$. Leucine, valine arylamidase and $\alpha$-chymotrypsin reactions tested with the
API ZYM system were only positive for strain DV $1140^{\mathrm{T}}$. The $\mathrm{G}+\mathrm{C}$ content of the genomic DNA of strain DV1140 ${ }^{\mathrm{T}}$ is $3 \mathrm{~mol} \%$ higher than that of Thermosipho geolei SL $31^{\mathrm{T}}$ and is the highest yet found for the genus Thermosipho (29-31.4 mol\%).

Based on phenotypic and genotypic differences between strain DV $1140^{\mathrm{T}}$ and its nearest described relative, we propose that DV $1140^{\mathrm{T}}$ should be assigned to a novel species of the Thermosipho genus belonging to the Thermotogales. Owing to its geographical origin, and in accordance with the protocol used to name previously described Thermosipho species, the name Thermosipho atlanticus sp. nov. is proposed for this novel species.

\section{Description of Thermosipho atlanticus sp. nov.}

Thermosipho atlanticus (at.lan'ti.cus. L. masc. adj. atlanticus from the Atlantic Ocean, referring to the site of isolation of the type strain).

Rod-shaped, non-motile, Gram-negative bacteria surrounded by a sheath-like structure. Growth occurs at $45-80{ }^{\circ} \mathrm{C}$ (optimum $65^{\circ} \mathrm{C}$ ), at $\mathrm{pH} 5 \cdot 0-9 \cdot 0$ (optimum 
$\mathrm{pH} 6 \cdot 0)$ and at sea salt concentrations of $20-60 \mathrm{~g} \mathrm{l}^{-1}$ (optimum $30 \mathrm{~g} \mathrm{l}^{-1}$ ). Anaerobic, resistant to concentrations of oxygen up to $4 \%$, heterotrophic, able to ferment BHI and also starch, galactose, arabinose, glucose, trehalose, cellobiose and gelatin in the presence of peptone and yeast extract. Elemental sulfur does not enhance growth. The $\mathrm{G}+\mathrm{C}$ content of the genomic DNA is $33 \mathrm{~mol} \%$.

The type strain, DV1140 $\left(=\right.$ CIP $108053^{\mathrm{T}}=$ DSM $\left.15807^{\mathrm{T}}\right)$, was isolated from a sample collected on the Menez-Gwen hydrothermal site on the Mid-Atlantic Ridge ( $31^{\circ} 31^{\prime} \mathrm{W} 37^{\circ}$ $51^{\prime} \mathrm{N}$; 800-1000 m water depth).

\section{Acknowledgements}

We thank C. Jeanthon (CNRS-UBO-IUEM, Plouzané, France) who kindly supplied Thermosipho geolei SL31 ${ }^{\mathrm{T}}$. We thank D. Desbruyères and A.-M. Alayse (IFREMER, Brest, France), chief scientists of cruise DIVA2. We thank the captain and crew of NO Nadir and the DSV Nautile pilots and support crew. We thank M.-A. Cambon-Bonavita (IFREMER, Brest, France) for her support in phylogenetic analyses. We also thank G. Sinquin (Université de Brest, France) for his technical support with transmission electron microscopy. This work was supported by IFREMER and the French Research Ministry (Décision d'aide no. 00 G 0178).

\section{References}

Alain, K., Pignet, P., Zbinden, M. \& 8 other authors (2002). Caminicella sporogenes gen. nov., sp. nov., a novel thermophilic spore-forming bacterium isolated from an East-Pacific Rise hydrothermal vent. Int J Syst Evol Microbiol 52, 1621-1628.

Altschul, S. F., Madden, T. L., Schaffer, A. A., Zhang, J., Zhang, Z., Miller, W. \& Lipman, D. J. (1997). Gapped BLAST and PSI-BLAST: a new generation of protein database search programs. Nucleic Acids Res 25, 3389-3402.

Antoine, E., Cilia, V., Meunier, J.-R., Guézennec, J., Lesongeur, F. \& Barbier, G. (1997). Thermosipho melanesiensis sp. nov., a new thermophilic anaerobic bacterium belonging the Thermotogales, isolated from deep-sea hydrothermal vent in the southern Pacific ocean. Int J Syst Bacteriol 47, 1118-1123.

Blumentals, I. I., Itoh, M., Olson, G. J. \& Kelly, R. M. (1990). Role of polysulfides in reduction of elemental sulfur by the hyperthermophilic archaebacterium Pyrococcus furiosus. Appl Environ Microbiol 56, 1255-1262.

Cord-Ruwisch, R. (1985). A quick method for the determination of dissolved and precipitated sulfides in cultures of sulfate-reducing bacteria. J Microbiol Methods 4, 33-36.

Fardeau, M.-L., Cayol, J.-L., Magot, M. \& Ollivier, B. (1993). $\mathrm{H}_{2}$ oxidation in the presence of thiosulfate, by a Thermoanaerobacter strain isolated from an oil-producing well. FEMS Microbiol Lett 113, 327-332.

Felsenstein, J. (1981). Evolutionary trees from DNA sequences: a maximum likelihood approach. J Mol Evol 17, 368-376.

Felsenstein, J. (1985). Confidence limits on phylogenies: an approach using the bootstrap. Evolution 30, 783-791.

Galtier, N., Gouy, M. \& Gautier, C. (1996). SEAVIEW and PHYLO_WIN: two graphic tools for sequence alignment and molecular phylogeny. Comput Appl Biosci 12, 543-548.

Gauthier, M. J. (1976). Alteromonas rubra sp. nov., a new marine antibiotic-producing bacterium. Int J Syst Bacteriol 26, 459-466.
Hofstad, T. (1980). Evaluation of the API ZYM system for identification of Bacteroides and Fusobacterium species. Med Microbiol Immunol 168, 173-177.

Huber, R., Woese, C. R., Langworthy, T. A., Fricke, H. \& Stetter, K. O. (1989). Thermosipho africanus gen. nov., represents a new genus of thermophilic eubacteria within the 'Thermotogales'. Syst Appl Microbiol 12, 32-37.

Kilian, M. (1978). Rapid identification of Actinomycetaceae and related bacteria. J Clin Microbiol 8, 127-133.

Kimura, M. (1980). A simple method for estimating evolutionary rates of base substitutions through comparative studies of nucleotide sequences. J Mol Evol 16, 111-120.

L'Haridon, S., Miroshnichenko, M., Hippe, H., Fardeau, M., Bonch-Osmolovskaya, E., Stackebrandt, E. \& Jeanthon, C. (2001). Thermosipho geolei sp. nov., a thermophilic bacterium isolated from a continental petroleum reservoir in Western Siberia. Int J Syst Evol Microbiol 51, 1327-1334.

Marmur, J. \& Doty, P. (1962). Determination of the base composition of deoxyribonucleic acid from its thermal denaturation temperature. J Mol Biol 5, 109-118.

Powers, E. M. (1995). Efficacy of the Ryu nonstaining $\mathrm{KOH}$ technique for rapidly determining Gram reactions of food-borne and waterborne bacteria and yeasts. Appl Environ Microbiol 61, 3756-3758.

Raguénès, G., Pignet, P., Gauthier, G., Peres, A., Christen, R., Rougeaux, H., Barbier, G. \& Guézennec, J. (1996). Description of a new polymer-secreting bacterium from a deep-sea hydrothermal vent, Alteromonas macleodii subsp. fijiensis, and preliminary characterization of the polymer. Appl Environ Microbiol 62, 67-73.

Raguénès, G., Christen, R., Guézennec, J., Pignet, P. \& Barbier, G. (1997). Vibrio diabolicus sp. nov., a new polysaccharide-secreting organism isolated from a deep-sea hydrothermal vent polychete annelid, Alvinella pompejana. Int J Syst Bacteriol 47, 989-995.

Saitou, M. \& Nei, M. (1987). The neighbor-joining method : a new method for reconstructing phylogenetic trees. Mol Biol Evol 4, 406-425.

Takai, K. \& Horikoshi, K. (2000). Thermosipho japonicus sp. nov., an extremely thermophilic bacterium isolated from a deep-sea hydrothermal vent in Japan. Extremophiles 4, 9-17.

Tharagonnet, D., Sisson, P. R., Roxby, C. M., Ingham, H. R. \& Selkon, J. B. (1977). The API ZYM system in the identification of Gram-negative anaerobes. J Clin Pathol 30, 505-509.

Thompson, J. D., Higgins, D. G. \& Gibson, T. J. (1994). CLUSTAL W: improving the sensitivity of progressive multiple sequence alignment through sequence weighting, position-specific gap penalties and weight matrix choice. Nucleic Acids Res 22, 4673-4680.

Urios, L., Cueff, V., Pignet, P. \& Barbier, G. (2004). Tepidibacter formicigenes sp. nov., a novel spore-forming bacterium isolated from a MidAtlantic Ridge hydrothermal vent. Int J Syst Evol Microbiol 54, 439-443.

Van Ooteghem, S. A., Beer, S. K. \& Yue, P. C. (2001). Hydrogen production by the thermophilic bacterium Thermotoga neapolitana. In Proceedings of the 2001 DOE Hydrogen Program Review, document no. NREL/CP-570-30535. Golden, CO: National Renewable Energy Laboratory.

Wery, N., Lesongeur, F., Pignet, P., Derennes, V., CambonBonavita, M., Godfroy, A. \& Barbier, G. (2001a). Marinitoga camini gen. nov., sp. nov., a rod-shaped bacterium belonging to the order Thermotogales, isolated from a deep-sea hydrothermal vent. Int J Syst Evol Microbiol 51, 495-504.

Wery, N., Moricet, J., Cueff, V., Jean, J., Pignet, P., Lesongeur, F., Cambon-Bonavita, M. \& Barbier, G. (2001b). Caloranaerobacter azorensis gen. nov., sp. nov., an anaerobic thermophilic bacterium isolated from a deep-sea hydrothermal vent. Int J Syst Evol Microbiol 51, 1789-1796. 